\title{
The Presence of Description on Spirometry Disorder in the Old TB Patients who were Suffering from Dyspnea in BBKPM Surakarta
}

\author{
Muhammad Ali*, Riana Sari*, Sri Wahyu Basuki* \\ *Korespondensi Author: swb191@ums.ac.id \\ *Universitas Muhammadiyah Surakarta, Kartasura, Sukoharjo, Central Java, Indonesia \\ I N D E X I N G \\ Keywords: \\ Tuberculosis; \\ Old TB; \\ Spirometry; \\ Dyspnea; \\ Obstruction;

\begin{abstract}
A B S T R AC T
Tuberculosis (TB) is an infectious disease caused by Mycobacterium tuberculosis signified by the formation of granuloma by the infected tissue. Old TB is a case of TB that once suffered from tuberculosis infection and declared as being cured. This reasearch aims to know the presence of description on spirometry disorder in the old TB patients who were suffering from dyspnea in BBKPM Surakarta. Type of this research is a descriptive research using Cross Sectional approach. Population which becomes the subject of this research is the outpatient in the Non TB Clinic of BBKPM Surakarta according to the criteria. Sampling was conducted using the method of Purposive Sampling and it was obtained 50 samples of old TB patients who were suffering from Dyspnea. Data were then processed by editing, coding, and tabulation. From the results of the data processing through editing, coding, and tabulation, there were 27 patients who were suffering from Obstruction disorder, 5 patients were suffering from Restriction disorder, 17 patients were suffering from mixed disorder (Obtruction and Restriction), and 2 patients were Normal. This research concluded who were
\end{abstract} \\ suffering from dyspnea, in BBKPM Surakarta.
}

Kata Kunci:

Tuberculosis;

Bekas TB;

Spirometri;

Dispnea;

Obstruksi;

Tuberkulosis (TB) adalah suatu penyakit infeksi menular yang di sebabkan oleh Mycobacteriun tuberculosis yang ditandai dengan terbentuknya granuloma oleh jaringan terinfeksi. Bekas TB adalah kasus TB yang pernah mengalami infeksi tubekulosis dan dinyatakan sembuh. Penelitian ini bertujuan untuk mengetahui adanya gambaran kelainan spirometri pada pasien Bekas TB yang mengalami Sesak Napas di BBKPM Surakarta. Jenis penelitian ini adalah penelitian deskriptif dengan pendekatan CrossSectional. Populasi yang menjadi subjek penelitian adalah pasien rawat jalan di Klinik Non TB BBKPM Surakarta sesuai dengan kriteria. Pengambilan sampel delakukan dengan metode Purposive Sampling dan didapatkan 50 sampel pasien Bekas TB yang mengalami Sesak Napas. Data kemudian di olah dengan editing,coding dan tabulasi. Dari hasil pengelolahan data dengan editing, coding, dan tabulasi yaitu terdapat 27 pesien mengalami kelainan Obstruksi, 5 pasien mengalami kelainan Restriksi, 17 pasien mengalami kelainan Campuran (Obtruksi dan Restriksi) dan 2 pasien didapatkan Normal. Penelitian ini menyimpulkan bahwa terdapat Gambaran Kelainan Spirometri pada pasien Bekas TB yang mengalami Sesak di BBKPM Surakarta.

(C) 2019 JMMR. All rights reserved

Article history: Received 2018-Sep-13; Revised 2019-Mar-13; Accepted 2019-Apr-18

\section{INTRODUCTION}

Tuberculosis is still a public health problem in many countries, especially in developing countries the World Health Organization (WHO) in 2013 stated that around 9 million people in the world have been infected with tuberculosis bacteria. ${ }^{-1}$ In 2014 there were 9.6 million world population infected with tuberculosis bacteria. ${ }^{-}$In this decade there were 2.9 million deaths due to tuberculosis and HIV TB infection and most of them occurred in developing countries. ${ }^{-}$
Based on the Global Tuberculosis Control WHO report 2014 stated, Indonesia is ranked second in the number of the world's largest tuberculosis cases 1 million new cases per year after India. ${ }^{4}$ However, of course the problem in TB control is still very large and Indonesia still contributes $10 \%$ of TB cases in the world. With around 460,000 new patients per year and an incidence of $272 /$ 100,000 population and a mortality rate of TB of 64,000 per year or $25 / 100,000$ population. In addition, TB occurs in 
more than $75 \%$ of productive age (15-45 years) so that the economic losses caused by TB are quite large..$^{5}$

The coverage of all pulmonary TB cases in the Central Java region was 36,759 cases, or 144 per 100,000 populations. The discovery of pulmonary TB patients at the Center for Lung Health in Surakarta Community reached 5,290 new cases recorded or 277 per 100,000 population in 2015. . $^{-}$

A study showed that old TB patients with pulmonary physiological disorders were found to reach 37 patients from 99 ex-TB samples that were investigated with an incidence rate of $37.4 \%$. From the results of ex-TB studies that have been carried out pulmonary physiology showed a pulmonary physiological disorder consisting of obstructive disorderswithFEV1 values decreased so that the ratio of FEV1 / FVC\% $<70 \%$ was found to be (54.1\%) and restriction pulmonary physiological disorder with FEV1 value and FVC remains or rises so that $70 \% \mathrm{FEV} 1 / \mathrm{FVC}$ is found to be $(41.9 \%)$. The most common residual symptoms are pulmonary physiological disorders with obstructive abnormalities that have a clinical picture similar to Chronic Obstructive Pulmonary Disease (COPD). ${ }^{7}$

Based on the information above, researchers are interested in conducting research. This study is different from the previous study in the sample group; the number of samples, the characteristics of the sample will be adjusted to the people of Surakarta who experienced shortness of TB, namely the Modified Medical Research Council Dyspnea Score and pneumobile data. Researchers wanted to know the presence of description on spirometry disorder in the old TB patients who were suffering from dyspnea in BBKPM Surakarta

This research aims to know the presence of description on spirometry disorder in the old TB patients who were suffering from dyspnea in BBKPM Surakarta.

\section{RESEARCH METHOD}

In this study using a descriptive cross sectional research type, which is done purely to signify the description without an in-depth analysis. ${ }^{-}$Subjects in this study were old TB patients who experienced shortness with a spirometry test at BBKPM Surakarta. Sampling was done by purposive sampling method, which is where the selection of subjects based on certain traits or traits related to the characteristics of the subject in which the subject of the study carried out breath measurements using spirometry. Data processing in research subjects is presented by editing, coding, and tabulating steps.

\section{RESULT AND DISCUSSION}

Table 1. Distribution of Old TB Patient Spirometry Disorders

\begin{tabular}{lcc}
\hline \multicolumn{1}{c}{ Abnormalities } & Frequency & Percentage \\
\hline Normal & 1 & 2 \\
Obstruksi & 27 & 54 \\
Restriksi & 5 & 10 \\
Combination & 17 & 34 \\
$\quad$ Total & $\mathbf{5 0}$ & $\mathbf{1 0 0}$ \\
\hline
\end{tabular}

Source: Primary Data Processed, August 2016

Based on the tabulation of spirometry calculation results above shows the majority of spirometry abnormalities in old TB patients who experience shortness of breath are obstruction as many as 27 people (54\%), 17 people (34\%) experience mixed disorders (obstruction restriction), 5 people $(10 \%)$ experiencing restriction abnormalities, and 1 person (2\%) did not experience spirometry abnormalities.

Table 2. Distribution of Sample Grade of Breathlessness of Old TB Patients

\begin{tabular}{ccc}
\hline Breathless & Frequency & Percentage \\
\hline Grade 1 & 24 & 48 \\
Grade 2 & 18 & 36 \\
Grade 3 & 7 & 14 \\
Grade 4 & 1 & 2 \\
Total & $\mathbf{5 0}$ & $\mathbf{1 0 0}$
\end{tabular}

Source: Primary Data Processed, August 2016

Based on the tabulation of the results of the calculation of breathlessness above shows most of the grade of shortness of breath in old TB patients is grade 1 as many as 24 people (48\%), grade 2 as many as 18 people $(36 \%)$, grade 3 as many as 7 people (14\%) and grade 4 only 1 person $(2 \%)$.

In this study, obstruction abnormalities were most often expressed by the delay in air flow in the respiratory tract due to the appearance of lung tissue. According to (PDPI, 2010), obstruction abnormalities that cause a decrease in FEV1 are caused by inflammation and narrowing of the peripheral airways, while decreased gas transfer occurs due to damage to the lung parenchyma.

Air flow limitation is influenced by the level of inflammation, fibrosis, and exudate fluid in the small airway lumen which correlates with a decrease in FEV1 and FEV1 / FVC ratio. A decrease in FEV1 is a typical symptom in COPD, but in former TB there can be a decrease in FEV1 and have symptoms similar to COPD. 
This peripheral airway obstruction causes trapped air and results in hyperinflation. Hyperinflation reduces inspiration capacity such as increased functional residual capacity, which is seen as shortness of breath and limited exercise capacity. Hyperinflation develops at the beginning of the disease is a common mechanism for the onset of breathlessness in activity. ${ }^{?}$

TB patients who have recovered can be found in two conditions, TB lesions can be absorbed by the body and healed without leaving marks or lesions healed but leaving fibrous tissue. ${ }^{10}$ Fibrosis occurs when extra cellular matric (ECM) has been destroyed by injury..$^{-1}$

Old $\mathrm{TB}$ Used $\mathrm{Tb}$ has a history of pulmonary tuberculosis with extensive fibrosis more often found atrophy and muscle retraction intercostalis..$^{10}$ It can cause lung expansion or reduction barriers complien lungs. The fibrosis tissue formed will reduce lung elasticity. ${ }^{12,13}$. Barriers to lung development cause restriction disorders. In restriction conditions, vital capacity (VC)\% prediction $<80$. $\frac{12}{\text {. }}$

In addition to restriction disorders, TB disease can cause obstruction or is known as post-TB syndrome. ${ }^{10}$ In the case of obstruction, small airways may experience collapse during expiration, preventing air from passing through this channel. $\stackrel{13}{-}$

In restriction disorders or restriction ventilation disorders are disorders characterized by an increase in lung, thoracic or both, due to a decrease in tension and a decrease in all lung volumes, including vital capacities. $\frac{14}{-}$

According to (Raghu et al, 2011) there was a decrease in FVC and predictive FVC / FVC ratio due to extensive destruction of the lung parenchyma, resulting in the lungs not working optimally, resulting in decreased lung function..$^{15}$

In another study conducted by Velada et al, 2013 anatomically, people who have high posture have a function of ventilation larger than those of small and short people. $\frac{16}{}$

In combination spirometry abnormalities (restricity and obstruction) caused by a combination of obstruction and restriction abnormalities. As long as the measurement of spirometry is measured the value of the FEV1 / FVC ratio decreases. $\frac{17}{}$

Under normal lung conditions, spirometry does not decrease in value of vital capacity and lung volume. ${ }^{18}$ In old TB patients who perform spirometry examination, normal results are obtained for lung capacity and lung volume values. According to Shetty AJ et al, 2010 when patients suffering from TB have received the right treatment, fast, and complete, so that patients get maximum recovery. $\frac{19}{}$
In this study, the grade of breathlessness according to the Modified Medical Research Council Dyspneu Scores (MMRCDS) scale developed by (Fletcher et al, 2009), was the highest grade 1, which was 27 events $(54 \%) .^{-\frac{20}{}}$ Many people suffer from shortness of breath because they are often exposed to dirty air pollution, dust, smoking habits, and lack of personal protective equipment, as well as chronic tuberculosis infections resulting in decreased lung function. ${ }^{-}$

\section{CONCLUSION}

Based on the results of research on spirometry abnormalities in former pulmonary tuberculosis patients who experienced shortness of breath in BBKPM Surakarta was an obstruction characterized by a decrease in FEV1\% predictive value in spirometry examination, and grade of shortness of breath in oldpulmonary TB patients found to be mostly grade 1 .

\section{REFERENCE}

1. World Health Organization (WHO) 2013. Global Tuberculosis Report. Switzerland.

2. World Health Organization (WHO) 2015. Global Tuberculosis Report. Switzerland.

3. Soetikno, A, et al, 2011. Internal medicine textbook. Jakarta: Center for Publishing the Department of Internal Medicine FKUI.

4. World Health Organization (WHO) 2014. Global Tuberculosis Report. Switzerland.

5. Ministry of Health RI, 2015. National TB Control Strategy in Indonesia.

6. Data BBKPM Surakarta (Balai Besar Kesehatan Paru Masyarakat Surakarta), 2015. Medical Record Installation Unit.

7. Irawati A, 2013., Occurrence of Post Tubularosis Obstruction Syndrome at RSU. Dr. Soedarso. Pontianak

8. Sopiyudin, D., 2011. Creating a research proposal medicine and health fields : Evidence Based Medicine.

9. PDPI (Perhimpunan Dokter Paru Indonesia). 2010. Tuberculosis Diagnosis and Management Guidelines in Indonesia. Indah Offset Citra Grafika. Jakarta.

10. Setiati, S, et all., 2015, Buku Ajar Ilmu Penyakit Dalam, edition 6, publishing center for internal medicine, Jakarta.

11. Robbins, Kumar, Cotran, 2007, Buku Ajar Patologi, Issue 7, EGC, Jakarta.

12. Primasakti, I., Sari, R, Basuki, S.W., 2016 Perbedaan Nilai Reratakvp \% Prediktis Dan Kv \% Prediksi 
Antara Orang Dengan Indeks Masa Tubuh Normal Dan Di Atas Normal, BIOMEDICA, VOL 1, NO.1, February, accessed December 6, 2018.

13. Sherwood, L., 2012 Fisiologi Manusia Dari Sel Ke Sistem, edition 6, EGC, Jakarta.

14. Price, A. dan Wilson, L. 2005. Patofisiologi. Book 2. Edisi 4. EGC. Jakarta, hal :1117-1119

15. Raghu G et al. 2011., Spirometry Clinical: a rational clinical approach. ;92:148-154

16. Vedala, S., Paul, N., Mane, B.A., 2013. Differences in Pulmonary Function Test among the Athletic and Sedentary Population. National Journal of Physiology, Pharmacy and Pharmacology. Vol 3: 2. 118 - 123.

17. Al-Ashkar, F., Mehra, R., Peter, J.M., 2003. Interpreting Pulmonary FunctionTests: Recognize the pattern, and the diagnosis will follow. Cleveland Clinic Journal of Medicine. 70:10.

18. Guyton, A.C., John, E.H., 2012. Textbook of Medical Physiology. Edisi 11. Jakarta: EGC

19. Shetty, A.J., Tyagi, A. 2010. Development of Post Tubercular, Bronchial Asthma - A Pilot Study. Journal of Clinical and Diagnostic Research. 4: 23602362.

20. Fletcher, A. J., Beers, M. H., Jones, T. V., Porter, R., 2009. The Merck Manual of Medical In formation. 2 nded. New York 